\title{
Assessment of Phytosanitary Practices in Peri-Urban Agriculture and Associated Environmental and Health Impacts in Developing Countries: Case of Abengourou City (Côte d'Ivoire)
}

\author{
Jean-Marie Pétémanagnan Ouattara ${ }^{{ }^{*}}$, Franck Michaël Zahui2 ${ }^{*}$, \\ Jean Rufin Kouassi Kouame ${ }^{1}$, Lacina Coulibaly ${ }^{1}$
}

\footnotetext{
${ }^{1}$ Department of Sciences and Environment Management, Nangui Abrogoua University, Abidjan, Côte d'Ivoire ${ }^{2}$ Department of Agronomic, Forestry and Environmental Engineering, University of Man, Man, Côte d'Ivoire Email: `jm_petemanagnan@yahoo.fr, ‘zahui_franck@yahoo.fr
}

How to cite this paper: Ouattara, P.J.-M., Zahui, F.M., Kouame, J.R.K. and Coulibaly, L. (2021) Assessment of Phytosanitary Practices in Peri-Urban Agriculture and Associated Environmental and Health Impacts in Developing Countries: Case of Abengourou City (Côte d'Ivoire). Journal of Agricultural Chemistry and Environment, 10, 275-288. https://doi.org/10.4236/jacen.2021.103017

Received: May 6, 2021

Accepted: June 25, 2021

Published: June 28, 2021

Copyright $\odot 2021$ by author(s) and Scientific Research Publishing Inc. This work is licensed under the Creative Commons Attribution International License (CC BY 4.0).

http://creativecommons.org/licenses/by/4.0/

\begin{abstract}
The use of phytosanitary products remains uncontrolled and abusive in the practice of market gardening in most developing countries. However, it remains one of the potential sources of environmental contamination and public health problems. This study examines the health and environmental risks associated with the use of phytosanitary products in market gardening in the town of Abengourou in Cote d'Ivoire. Field surveys carried out among all (30) market gardener sites housed 150 farmers showed that when the products were spread, no health and safety measures were observed. Approximately $80 \%$ of the respondents did not wear gloves or face masks. Some products used were not approved for market gardening. Farmers had itching, dizziness, headaches, colds and vomiting on a regular basis when applying the products. The study also revealed the presence of empty packaging in the surrounding surface water and on the ground. In addition to producers, this type of uncontrolled market gardening likely exposes consumers to high health risks and also contributes to environmental degradation. Raising awareness among stakeholders of good agricultural practices could help promote sustainable market gardening. However, studies of the effects of products in such an environment on the health of consumers deserve to be carried out.
\end{abstract}

\section{Keywords}

Phytosanitary Practices, Market Gardening, Health and Environmental Risks, 
Abengourou City, Côte d'Ivoire

\section{Introduction}

The growth of urban markets in sub-Saharan African countries has led to an expansion of agricultural practices in cities, with the uncontrolled use of phytosanitary products (pesticides) by market gardeners to increase their production [1]. Indeed, if peri-urban agriculture practices improve the living environment and play a positive role in the use of waste (Droppings) [2], the uncontrolled use of pesticides (i.e. insecticides, fungicides and herbicides) and various source of organic amendments lead to contamination of soils as well as surface and ground water, thus exposing populations to various pathologies [3] [4] [5] [6] [7].

Several studies carried out in the countries, including those by Cissé et al. [8] in Senegal, Kanda et al. [9] in Togo, Lawani et al. [10] in Benin, Tarnagda et al. [11] in Burkina Faso, Tchamadeu et al. [12] in Cameroon and Ado et al. [13] in Niger, noted very poor management of pesticides on market garden sites in urban areas of these countries. This concerns the reuse, burying and abandonment on sites of empty pesticide packaging as well as the poor storage of phytosanitary products which could constitute a threat to the biodiversity and productivity of natural ecosystems as well as to human health.

Proper pesticide use is crucial to farmers' health and environmental protection. Indeed, long-term pesticide exposure has been linked to the development of Parkinson's disease; asthma; depression and anxiety; attention deficit and hyperactivity disorder (ADHD); and cancer, etc. [14] [15]. Akter et al. [16] and Bertrand [17] noted several cases of toxicity symptoms among farmers in Bangladesh and Africa respectively, during the application of pesticides among which eye and skin irritation, nausea, vomiting, and headache were the most frequent symptoms.

In Côte d'Ivoire, the examination of phytosanitary practices by market gardeners and their impact on the sanitary quality of crops grown (carrots, lettuce, vegetables, onions, parsley, tomatoes, etc.) has been the subject of several studies in urban areas of certain regions. These are the regions of the south (Abidjan) [18] [19] [20], the center (Bouaké and Yamoussoukro) [21] [22] [23] and from the north (Korhogo) [24]. These investigations have shown that the phytosanitary products used were fungicides, insecticides and herbicides, generally acquired from non-approved resellers, most of which were not approved for market garden crops. In addition, most market gardeners did not observe any protective measures during phytosanitary treatments of crops. Thus, in order to understand the information relating to the use of phytosanitary products in urban market gardening, on a national scale, it appears necessary to extend these studies to other regions of the country. This would make it possible to develop policies to deal with this phenomenon. 
This study aims to examine the practice of market gardening in the town of Abengourou (capital of the "Indénié-Djuablin" region), in eastern Côte d'Ivoire. Specifically, this involves: 1) determining the socio-demographic profile of market gardeners and the types of crops grown; 2) identifying the phytosanitary products used and waste management on market gardening sites; and 3) assess the environmental and health risks associated with the use of phytosanitary products in market gardening.

\section{Materials and Methods}

Data collection for this study was carried out on market gardening sites in the city of Abengourou and required the use of a survey sheet, addressed to market gardeners, of a Global Position Satellite (GPS) for geo locate the various sites and a digital camera to take pictures of the environment of the market gardening sites.

\subsection{Study Area}

The city of Abengourou is located in the administrative region of IndéniéDjuablin of which it is the capital and is located between $6^{\circ} 43^{\prime} 47^{\prime \prime} \mathrm{N}$ and $3^{\circ} 29^{\prime} 47^{\prime \prime} \mathrm{W}$. It covers an area of $5744 \mathrm{~km}^{2}$. The city is located in the east of the country (Figure 1), precisely $210 \mathrm{~km}$ from Abidjan, on the Abidjan-Bondoukou axis. The climate

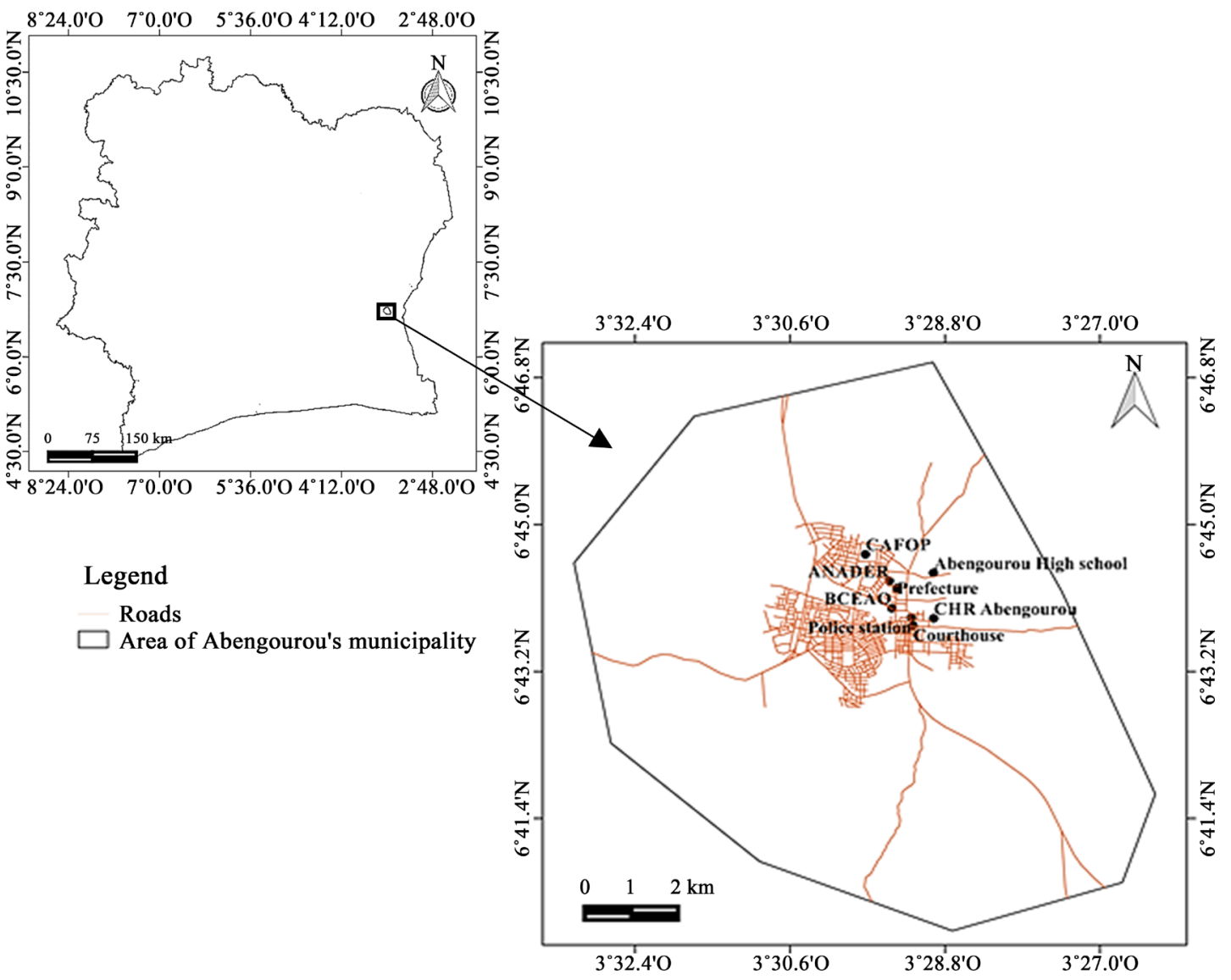

Figure 1. Location of the municipality of Abengourou. 
of the region comprises four (4) seasons divided into a large rainy season extending from April to July, a small dry season from July to September, a small rainy season from September to November and a large and very marked dry season from December to March. In this equatorial transition regime, the annual precipitation levels vary from 1400 to $2500 \mathrm{~mm}$ [25]. The city of Abengourou has a total of four (04) main types of soil, in particular weakly ferralitic soils in the North, moderately saturated soils in the South, weakly ferralitic soils on granite and alluvial soils in the lowlands and swamps which remain favourable to the practice of market gardening [26].

\subsection{Survey for Data Collection}

The survey was carried out from August to September 2019, on all of the city's market gardening sites (30), located in the plateau district, in particular in the lowlands of the Pedagogical Project in the Centers of Animation and Educational Training (CAFOP) and that of the Central Bank of West African States (BCEAO) in the city of Abengourou (Figure 2). The lowland of CAFOP has an area of 16 hectares and that of BCEAO is 6 hectares. There are a variety of cultural practices there (cucumber, lettuce, onion, parsley, tomato, etc.).

The survey consisted of collecting information relating to the socio-demographic profile of farmers, market gardening practices, waste management and environmental and health risks related to the activities carried out. Knowledge relating to market gardening practices concerned the types of crops grown, the types of phytosanitary products used, the methods of using phytosanitary products and the means of protection used by farmers. A total of 150 farmers were identified across all the market gardening sites and interviewed as part of the survey. Field observations consisted of assessing the state of the lowland environment in order to illustrate the types of crops and the impacts of activities on

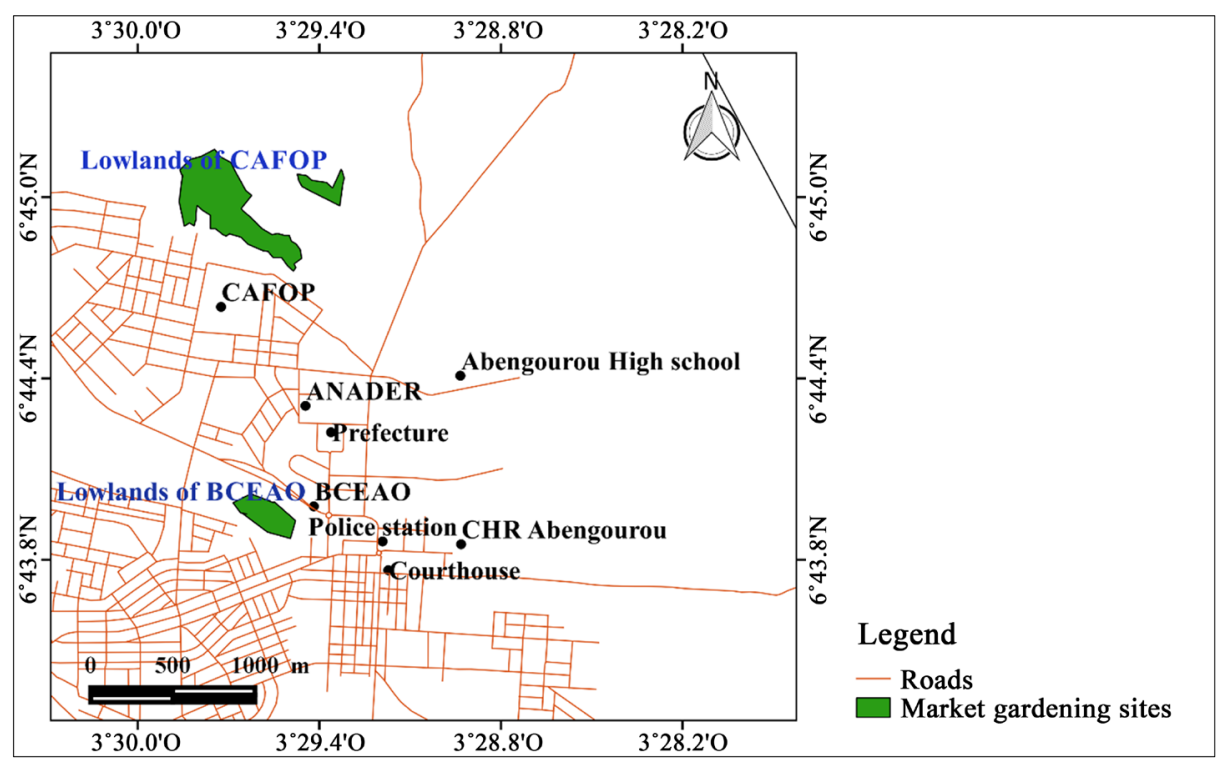

Figure 2. Location of market gardening sites in Abengourou. 
the environment through the management of phytosanitary waste (plastic, packaging of products already used, jars, etc.).

\subsection{Calcul and Statistics}

The data collected from the questionnaire were codified and then grouped by variables (socio-demographic profile, market gardening practices, waste management and environmental and health risks). The frequency of each variable was calculated in relation to the number of market gardeners questioned according to relation (1):

$$
F=\frac{X}{Y} \times 100
$$

where:

F: Frequency (\%);

$X$ : Number of the modality considered;

$Y$ : Total workforce of the modality considered.

The arithmetic mean made it possible to estimate the mean value of the size of the plots, calculated from the relation (2):

$$
\bar{X}=\frac{1}{n} \times \sum_{i=1}^{n} X_{i}
$$

where;

$$
\begin{aligned}
& \bar{X} \text { : Average value of the size of plots; } \\
& n=\text { Total number of market gardeners surveyed; } \\
& X_{i}=\text { Plot size }
\end{aligned}
$$

\section{Results and Discussion}

\subsection{Socio Demographic Characteristics of Market Gardeners}

Amount the total of 30 market gardening sites housing 150 farmers encountered in the lowlands of the city of Abengourou, the workforce was made up of 53.3\% women and $46.7 \%$ men (Table 1). This result is contrary to those of most similar

Table 1. Socio demographic characteristics of market gardeners.

\begin{tabular}{clc}
\hline \multicolumn{2}{c}{ Characteristics of market gardeners (Farmers) } & Percentage (\%) \\
\hline Gender of farmers & Male & 53.3 \\
Female farmers & Female & 46.7 \\
& Wives of farmers & 87.5 \\
Education level of farmers & Daughter heirs of farmers & 12.5 \\
& Secondary school education & 20 \\
& Primary school education & 13.3 \\
& No formal education & 66.7 \\
Market gardening training & No training received & 60 \\
\hline
\end{tabular}


studies carried out in certain regions of Côte d'Ivoire [18] [20], Togo [27] [28], Burkina Faso [29] and Cameroon [12], who reported a low rate of involvement of women in market gardening. Indeed, in Abengourou, we noticed the presence of rice fields upstream of market gardening sites, the owners of which were mostly by men who were mostly husbands of women working on market gardening sites located downstream. In fact, the women met at all of the sites (80) were mainly (87.5\%) wives of self-employed market gardeners and $12.5 \%$ of heiress daughters, as observed in Table 1.

Analysis of the education level of market gardeners showed that the schooling rate of market gardeners was low (Table 1). The rate of educated market gardeners was $33.3 \%$ against $66.7 \%$ of out-of-school. However, among that in school, $13.3 \%$ had limited primary school education and $20 \%$ had secondary education. This could be due to the cost of primary school enrolment at the time of the latter, unlike the free education nowadays, in the country. The result corroborates that of Kpan et al. [20] carried out in the municipality of Port-Bouët (Abidjan). Moreover, these authors believed that the lack of employment and the harsh selection forced non-graduates to practice market gardening in order to meet their needs. From local point of view, the low level of industrialization of the city of Abengourou will have reduced the chances of employability of the population whose level of study was mainly primary school. These results confirm with those of Banjo et al [30], Congo [31], Diop [32] and Tarnadga et al. [11], performed in certain sub-Saharan African countries, in which, the farmers had no training in market gardening for the most part like those in the present study. Indeed, only $40 \%$ of farmers had received training before market gardening, against $60 \%$ (Table 1).

\subsection{Market Gardening Practice}

The average number of farmers in each market gardening site was 5 farmers. However, three (3) classes were distinguished (Table 2), in particular the market gardening plots which house 1 to 3 farmers, the most numerous (43.3\%), then come the plots housing 3 to 5 farmers, the proportion of which was $33.3 \%$ of market gardening sites. Finally, those which housed more than 5 farmers represented $23.4 \%$. We noted in the same table that market gardening activities have been practiced on most of the plots (88\%) for more than 5 years. On the other hand, $12 \%$ of market garden sites are less than 5 years old.

The crops grown at the sites consist of eggplant, cucumber, lettuce, mint, onion, parsley and tomato. However, lettuce was grown on all plots. It is followed by onion, parsley and mint, which are practiced on $66.7 \%, 60 \%$ and $40 \%$ of sites, respectively. Eggplant remains the least practiced by market gardeners (16\%). This production system characterized by a plurality of crops is similar to those observed by Kouakou et al. [18], Obuodi et al. [33], Fondio et al. [21], Tano et al. [22] and Kanda et al. [9]. The diversity of market garden species is attributed by these authors to short crop cycles, ranging from 30 to 45 days and to 
the high demand for these crops by consumers. In fact, these are vegetable species necessary for a balanced diet, rich in nutrients (i.e. carotene, vitamin B and C, proteins, etc.) [34] [35]. This same observation has been made by several authors, notably Diao [2] in Senegal, Dongmo et al. [36] in Cameroon, Tallaki [37] in Togo and Kouakou et al. [18] in Côte d'Ivoire. Figure 3 illustrates the most dominant crops (lettuce, onion, parsley, mint) on the market gardening sites visited.

\subsection{Use of Phytosanitary Products in Market Gardening}

Farmers use chemical fertilizers (NPK and urea fertilizers), organic fertilizers (poultry droppings) and phytosanitary products in their market gardening activities (Figure 4). The most widely used phytosanitary products consist of $45 \%$ herbicides followed by fungicides (30\%) and insecticides (25\%) (Table 3). According to Cissé et al. [8] and Kouakou et al. [18], market gardeners use these products to fight against hazards, ensure soil fertility, and protect crops against pests, rot and weeds. Indeed, the major constraints of vegetable production are linked to the attack of weeds and the proliferation of pest macro invertebrates, made favourable by the soil of the lowlands [38]. In addition, the lack of fallow

Table 2. Market gardening practice on the plots.

\begin{tabular}{clc}
\hline Market gardening sites & & Percentage (\%) \\
\hline Number of farmers per market gardening plot & {$[1 ; 3[$} & 43.3 \\
& {$[3 ; 5[$} & 33.3 \\
& {$[5 ;$ plus [} & 23.4 \\
\hline Types of crops grown & Eggplant & 16.7 \\
& Cucumber & 26.7 \\
& Lettuce & 100 \\
& Mint & 40 \\
Duration of cultivation practice & Onion & 66.7 \\
& Parsley & 60 \\
\hline \multirow{2}{*}{ Ty years } & 12 \\
\hline
\end{tabular}
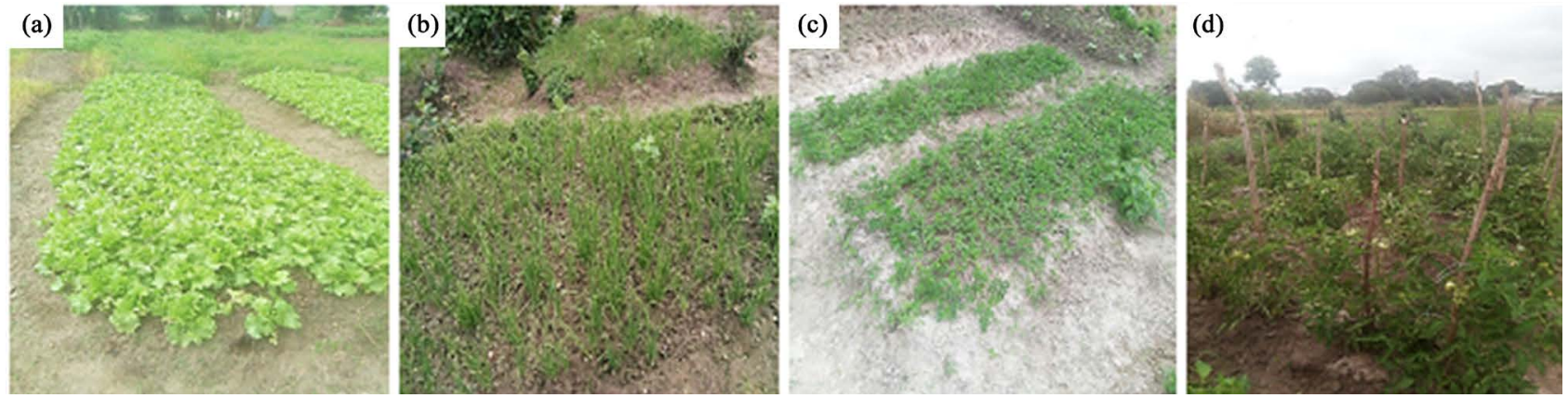

Figure 3. View of the most cultivated crops in the study area. (a) Lettuce crop; (b) Onion crop; (c) Parsley crop; (d) Tomato crop. 

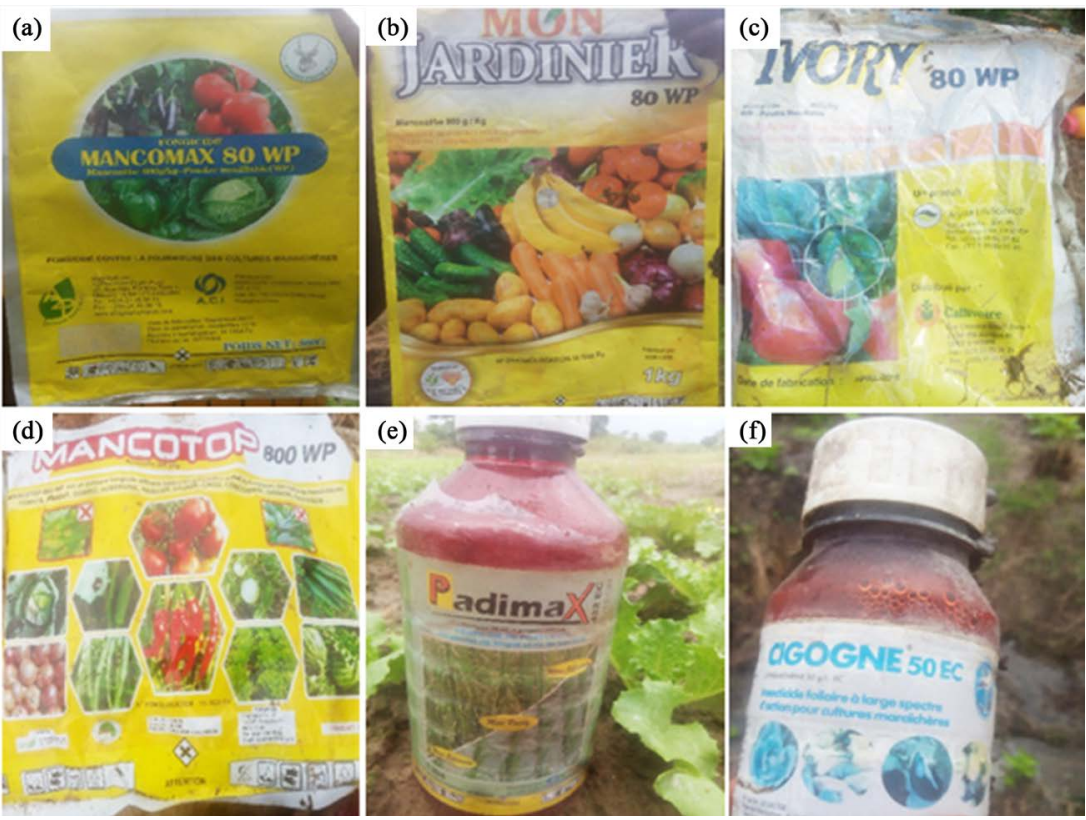

Figure 4. View of the empty packaging of the products used in market gardening activities. (a) = Mancomax $80 \mathrm{WP}$; (b) = Mon jardinier $80 \mathrm{WP}$; (c) = Ivoiry $80 \mathrm{WP}$; (d) = Mancotop $800 \mathrm{WP}$; (e) = Padimax 432 EC; (f) = Cigogne 50 EC.

Table 3. Characteristics of phytosanitary products used by market gardeners.

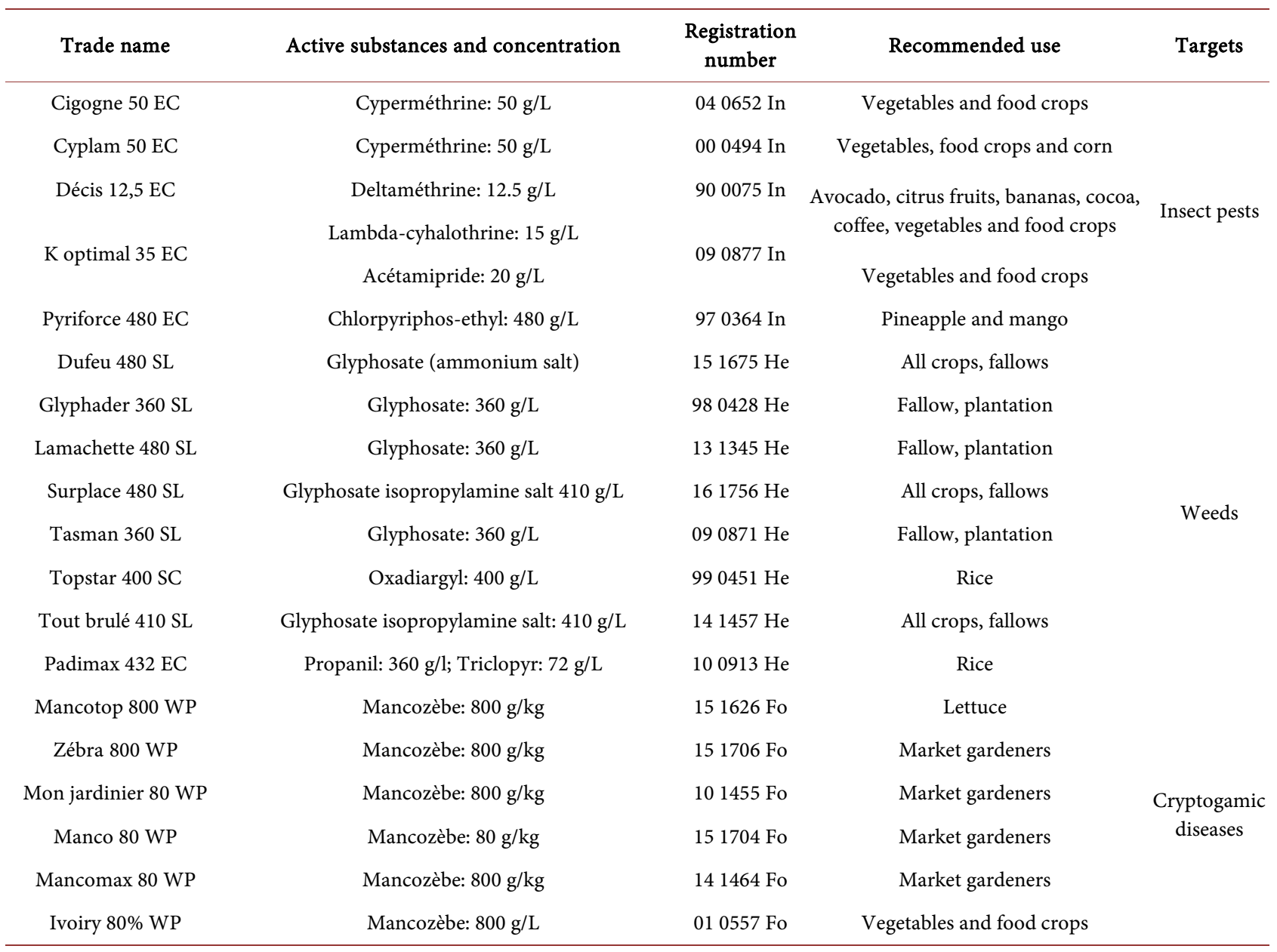


in market gardening due to insufficient cultivable land contributes to further depleting these soils [38].

However, during the investigation, the use of non-approved products for market gardening was recorded. This is the case with agrochemicals such as Pyriforce 480 EC, Padimax 432 EC, Décis 12.5 EC and Topstar 400 SC (Table 3), registered for crops of pineapple, avocado, citrus, banana, mango and rice, but unfortunately used in market gardening in the city of Abengourou. This situation could be related to the costs, probably less expensive, of these agrochemical specialties. Doumbia and Kwadjo [19] and Kpan et al. [20] noted the use of approved products for growing cotton (i.e. Stater $350 \mathrm{EC}$, Calfos $720 \mathrm{EC}$, Curacron 500 EC and Polytrine 186 EC) by market gardeners in Abidjan and its suburbs (eg. Portbouët, Dabou and Anyama). Indeed, these products were sold at low prices thanks to a subsidy which benefited cotton farmers [19].

In addition, the use of phytosanitary products in high proportions of herbicides followed by fungicides and insecticides is similar in Côte d'Ivoire [20] [22] [38] and in the sub-region [8] [11] [32] [39]. According to Kouakou et al. [38], this situation could be explained by the major constraint of market gardening sites due to the strong pressure from adventitious plants and pest parasites.

\subsection{Waste Management on Market Gardening Sites}

The waste encountered on market gardening sites consists of empty packaging of phytosanitary products (i.e. cans and sachets), ordinary sachets used to transport the products, leftover poultry droppings used as fertilizer and used working equipment [i.e. watering cans, cans, sprayers, etc.] (Figure 5). This waste was dominated by empty packaging of (97\%) at the various sites. The remains of droppings, used working equipment and ordinary sachets are very little encountered at the respective proportions of $1.5 \%, 1 \%$ and $0.5 \%$ (Table 4 ). These wastes were mostly abandoned by the majority of market gardeners $(60 \%)$ on the sites, both on land and in the water points used for watering crops. Waste management on the sites can be attributed to the low level of education of market gardeners, who do not generally consult the labels of product packaging [8] [40]. Similar results were obtained by Son et al. [41] in Burkina, where the identified waste believed to be the source of soil and water contamination of the study sites.

\subsection{Health Impact}

All market gardeners interviewed were aware of the risks associated with the use of phytosanitary products, both for their health and for the environment. However, $80 \%$ of market gardeners did not protect themselves during phytosanitary treatments and only washed their hands (87.5\%) after treating the plots (Table 4). Akter et al. [16] attribute this to the low educational level, the lack of knowledge, insufficient training and the pursuit of high profits of market gardeners. This would justify the pathologies (i.e. headaches, body itching, colds, vomiting 

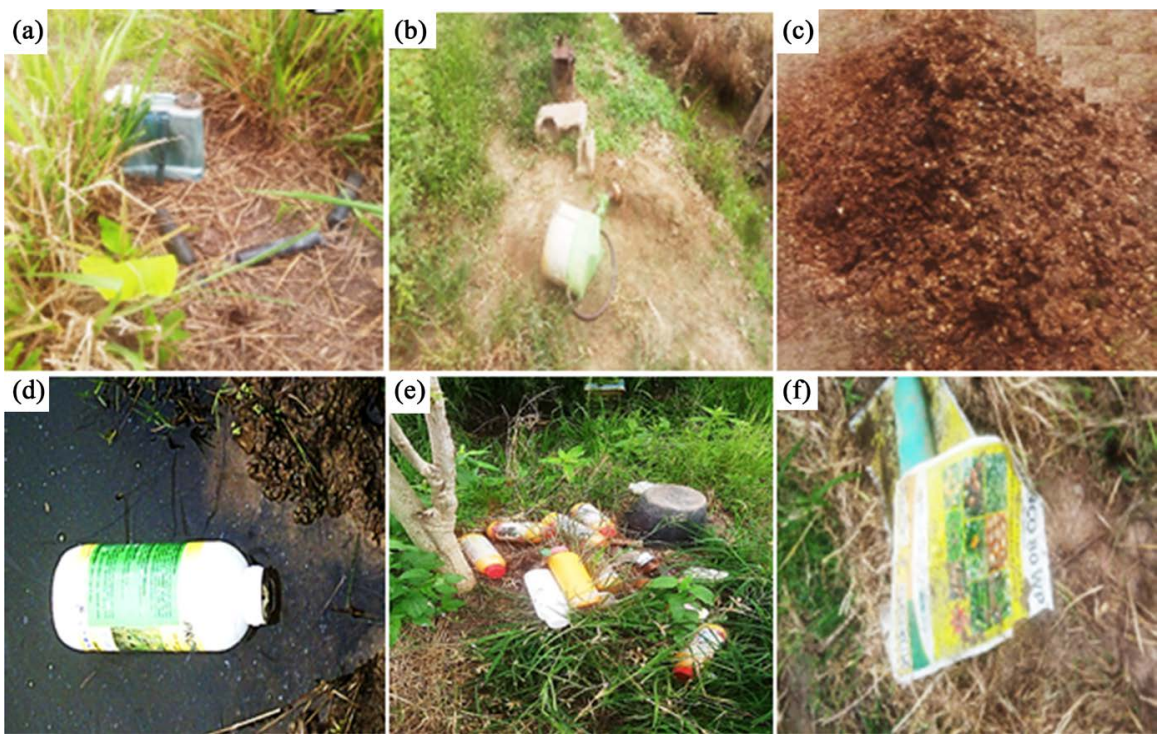

Figure 5. View of the waste encountered on the market gardening sites. (a) = Damaged sprayer; (b) = Damaged watering cans; $(\mathrm{c})$ = Manure; $(\mathrm{d})$ = Empty packaging in water; (e); (f) = Empty packaging of sachet and canister products on land.

Table 4. Waste production and management on market gardening sites and safety measures.

\begin{tabular}{|c|c|c|}
\hline \multicolumn{2}{|c|}{ Waste on market gardening sites } & \multirow{2}{*}{$\begin{array}{c}\text { Percentage (\%) } \\
97\end{array}$} \\
\hline \multirow{4}{*}{$\begin{array}{l}\text { Types of waste produced per } \\
\text { market gardening sites }\end{array}$} & Empty packaging of phytosanitary products & \\
\hline & Ordinary sachets & 1 \\
\hline & Poultry droppings & 1.5 \\
\hline & Worn work equipment & 0.5 \\
\hline \multirow{2}{*}{$\begin{array}{l}\text { Disposal of waste on market } \\
\text { gardening sites }\end{array}$} & Landfill of packaging on site & 40 \\
\hline & Abandonment on site & 60 \\
\hline \multirow{3}{*}{ Health and safety measures } & No use of protective equipment & 80 \\
\hline & Gloves & 6.7 \\
\hline & Face masks & 13.3 \\
\hline \multirow{2}{*}{$\begin{array}{l}\text { Behavior after application of } \\
\text { phytosanitary products }\end{array}$} & Hands only washed & 87.5 \\
\hline & Body entirely washed & 12.5 \\
\hline
\end{tabular}

and dizziness) manifested by market gardeners on the various sites [42]. In fact, 93.3\% of them indicated having suffered or still suffered from headaches, $90 \%$ from body itching. Then come colds, vomiting and dizziness, manifested respectively in $83.3 \%, 80 \%$ and $76.7 \%$ of market gardeners (Figure 6). These same pathologies have been reported by Doumbia and Kwadjo [19], Banjo et al. [30], Ngom et al. [39], Congo [31], Diop [32] and Kpan et al. [20], on market garden sites.

\section{Conclusion}

The agricultural practices observed by market gardeners in Abengourou city did 


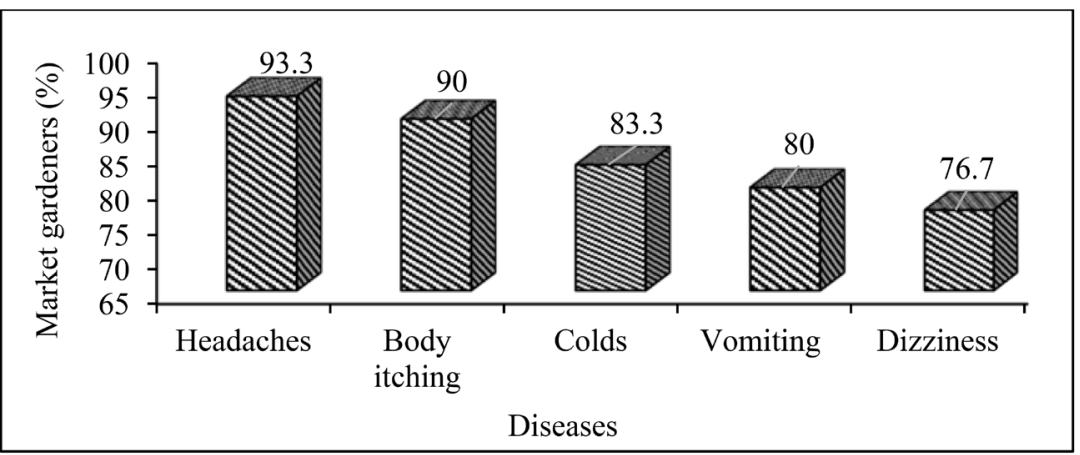

Figure 6. Diseases commonly contracted by the market gardeners on plots.

not comply with good phytosanitary practices. Some of the phytosanitary products used were not suitable for market gardening. Farmers ensured the production of food at the cost of their health because they applied phytosanitary products without proper protection. All the practices observed led to improper management of empty pesticide packaging on production sites. Indeed, this can lead to the risk of diseases identified in market gardeners and also pollute the surrounding ecosystem. To remedy this situation, support measures such as financing funds, training and monitoring must be applied to stakeholders in order to promote sustainable market gardening that takes into account the health of stakeholders and the environmental protection in the city of Abengourou. In addition, studies related to the quality of cultivated soils, surrounding surface water and that of products obtained from market gardening crops would further contribute to much better protection of the environment and the health of the populations.

\section{Conflicts of Interest}

The authors declare no conflicts of interest regarding the publication of this paper.

\section{References}

[1] Temple, L. and Moustier, P. (2004) Les fonctions et contraintes de l'agriculture périurbaine de quelques villes africaines (Yaoundé, Cotonou, Dakar). Cahier Agricultures, 13, 15-22.

[2] Diao, B.M. (2004) Situation et contraintes des systèmes urbains et périurbains de production horticole et animale dans la région de Dakar. Sénégal. Cahier Agricultures, 13, 39-49.

[3] Tapsoba, H.K. and Bonzi-Coulibaly, Y.L. (2006) Production cotonnière et pollution des eaux par les pesticides au Burkina Faso. Journal de la Société Ouest-Africaine de Chimie, 21, 87-93.

[4] Ahouangninou, C., Fayomi, B.E. and Martin, T. (2011) Evaluation des Risques Sanitaires et Environnementaux des Pratiques Phytosanitaires des Producteurs Maraîchers dans la Commune Rurale de Tori-Bossito (Sud-Bénin). Cahiers Agricultures, 20, 216-222. https://doi.org/10.1684/agr.2011.0485

[5] Panuwet, P., Siriwong, W., Prapamontol, T., Barry Ryan, P., Fiedler, N., Robson, 
M.G. and Boyd Barr, D. (2012) Agricultural Pesticide Management in Thailand: Status and Population Health Risk. Environmental Science \& Policy, 17, 72-81. https://doi.org/10.1016/j.envsci.2011.12.005

[6] Kumar, A. and Singh, S. (2013) Adsorption and Desorption Behavior of Chlorotriazine Herbicides in the Agricultural Soils. Journal of Petroleum \& Environmental Biotechnology, 4, 154.

[7] Naré, R.W.A., Savadogo, P.W., Gnankambary, Z., Nacro, H.B. and Sedogo, M. (2015) Analyzing Risks Related to the Use of Pesticides in Vegetable Gardens in Burkina Faso. Agriculture, Forestry and Fisheries, 4, 165-172. https://doi.org/10.11648/j.aff.20150404.13

[8] Cissé, I., Tandia, A.A., Fall, S.T. and Diop, E.S. (2003) Usage incontrôlé des pesticides en agriculture périurbaine: Cas de la zone des Niayes au Sénégal. Cahier Agriculture, 12, 181-186.

[9] Kanda, M., Wala, K., Djanaye-Boundjou, G., Ahanchebe, A. and Akpagana, K. (2013) Application des pesticides en agriculture maraichère au Togo. Vertigo, 13, 4-8. https://doi.org/10.4000/vertigo.13456

[10] Lawani, A.N., Kelome, N.C., Agassounon, D.T.M., Hounkpe, J.B. and Adjagodo, A. (2017) Effects of Agricultural Practices on the Pollution of Surface Water in Benin Republic. Larhyss Journal, 30, 173-190.

[11] Tarnagda, B., Tankoano, A., Tapsoba, F., Sourabié, P.B., Abdoullahi, H.O., Djbrine, A.O., Drabo, K.M., Traoré, Y. and Savadogo, A. (2017) Évaluation des pratiques agricoles des légumes feuilles: Le cas des utilisations des pesticides et des intrants chimiques sur les sites maraîchers de Ouagadougou, Burkina Faso. Journal of Applied Biosciences, 117, 11658-11668. https://doi.org/10.4314/jab.v117i1.3

[12] Tchamadeu, N.N., Nkontche, K.D. and Nana, D.E. (2017) Évaluation des facteurs de risques environnementaux liés à la mauvaise utilisation des pesticides par les maraîchers au Cameroun: Le cas de Balessing à l'Ouest Cameroun. Afrique Science, 13, 91-100.

[13] Ado, S.M.N., Tankari, D.B.A., Güero, Y., Guéro, Y., Tidjani, A.D., Danlasmon, N. and Ambouta, K.J.M. (2018) Diagnosis of Pesticide Use in Oasian Interdunal Depressions of the Gouré Area. Geo-Eco-Trop, 42, 343-350.

[14] Atreya, K. (2008) Probabilistic Assessment of Acute Health Symptoms Related to Pesticide Use under Intensified Nepalese Agriculture. International Journal of Environmental Health Research, 18, 187-208. https://doi.org/10.1080/09603120701694083

[15] Conant, J. and Fadem, P. (2012) A Community Guide to Environmental Health. Hesperian Health Guides, Berkeley.

[16] Akter, M., Fan, L., Rahman, M., Geissen, V. and Ritsema, C.J. (2018) Vegetable Farmers' Behaviour and Knowledge Related to Pesticide Use and Related Health Problems: A Case Study from Bangladesh. Journal of Cleaner Production, 200, 122-133. https://doi.org/10.1016/j.jclepro.2018.07.130

[17] Bertrand, P.G. (2019) Uses and Misuses of Agricultural Pesticides in Africa: Neglected Public Health Threats for Workers and Population. In: Larramendy, M.L., Ed., Pesticides Use and Misuse and Their Impact in the Environment, IntechOpen, London, $14 \mathrm{p}$.

[18] Kouakou, Y.E., Koné, B., Bonfoh, B., Kientga, S.M., N’Go, Y.A., Savane, I. and Cissé, G. (2010) L'étalement urbain au péril des activités agro-pastorales à Abidjan. Vertigo, 10, 1-9.

[19] Doumbia, M. and Kwadjo, K.E. (2009) Pratiques d'utilisation et de gestion des pes- 
ticides par les maraîchers en Côte d'Ivoire: Cas de la ville d'Abidjan et deux de ses banlieues (Dabou et Anyama). Journal of Applied Biosciences, 18, 992-1002.

[20] Kpan, K.K., Yao, B.L., Diemeleou, A.C., N'guettia, K., Traoré, K.S. and Dembelle, A. (2019) Pratiques phytosanitaires en agriculture périurbaine et contamination des denrées par les pesticides: Cas des maraîchers de Port-Bouët (Abidjan). Journal of Animal \& Plant Sciences, 41, 6847-6863. https://doi.org/10.35759/JAnmPlSci.v41-1.11

[21] Fondio, L., Kouame, C., Djidji, A.H. and Traore, D. (2011) Caractérisation des systèmes de culture intégrant le gombo dans le maraîchage urbain et périurbain de Bouaké dans le Centre de la Côte d'Ivoire. International Journal of Biological and Chemical Sciences, 5, 1178-1189. https://doi.org/10.4314/ijbcs.v5i3.72251

[22] Tano, B.F., Abo, K., Dembélé, A. and Fondio, L. (2011) Systèmes de production et pratiques à risque en agriculture urbaine: Cas du maraîchage dans la ville de Yamoussoukro en Côte d'Ivoire. International Journal of Biological and Chemical Sciences, 5, 2317-2329. https://doi.org/10.4314/ijbcs.v5i6.12

[23] Tiembré, I., Soumbre, Aka, E., Djoman, C., Benié, J., Ekra, D. and Gnagne, T. (2016) Impact environnemental et sanitaire de l'utilisation des pesticides dans le maraîchage urbain et périurbain dans la zone de Yamoussoukro, Côte d'Ivoire. $R e$ vue d' Épidémiologie et de Santé Publique, 64, 249-250.

https://doi.org/10.1016/j.respe.2016.06.291

[24] Soro, G., Koffi, N.M., Kone, B., Kouakou, Y.E., M’bra, K.R., Soro, P.D. and Soro, N. (2018) Utilisation des produits phytosanitaires dans le maraîchage autour du barrage d'alimentation en eau potable de la ville de Korhogo (nord de la Cote d'Ivoire): Risques pour la santé publique. Environnement Risque Santé, 17, 155-163.

[25] Girard, G., Sircoulon, J. and Touchebeuf, P. (1971) Aperçu sur les régimes hydrologiques. Le milieu naturel de la côte d'Ivoire. ORSTOM, Paris.

[26] Perraud, A. (1971). Les sols. In: Avenard, J.M., Eldin, M., Girard, G., Sircoulon, J., Touchebeuf, P., Guillaumet, J.L. and Adjanohoun, E., Eds., Le milieu naturel de la côte d Ivoire, ORSTOM, Paris, $391 \mathrm{p}$.

[27] Mawussi, G. (2008) Bilan environnemental de l'utilisation de pesticides organochlorés dans les cultures de coton, café et cacao au Togo et recherche d'alternatives par l'évaluation du pouvoir insecticide d'extraits de plantes locales contre le scolyte du café (Hypothenemus hampei Ferrari). PhD, Institut National Polytechnique de Toulouse, Toulouse.

[28] Mondedji, A.D. (2010) Potentiel d'utilisation d'extraits de feuilles de neem (Azadirachta indica $A$. Juss.) et de papayer (Carica papaya $L$.) dans le contrôle des insectes ravageurs du chou (Brassica oleracea $L$.) en zones urbaines et périurbaines au sud du Togo. Thesis, université Lomé, Togo.

[29] Ouattara, Z.A. (2016) Caractérisation des systèmes de produictions maraîchers et analyse des determinants de la fertilization des sols sous cultures maramichères dans la province du Houet (Burkina Faso). Diplôme d'ingénieur du dévéloppement rural à Université polytechnique de Bobo-dioulasso Burkina Faso.

[30] Banjo, A.D., Aina, S.A. and Rije, O.I. (2010) Farmers' Knowledge and Perception towards Herbicides and Pesticides Usage in Fadama Area of OkunOwa, Ogun State of Nigeria. African Journal of Basic and Applied Sciences, 2, 188-194. http://idosi.org/ajbas/ajbas2(5-6)10/10.pdf

[31] Congo, K. (2013) Risques sanitaires associes à l'utilisation de pesticides autour de petites retenues: Cas du barrage de loumbila. In Mémoire master 2iE, Ouagadougou Burkina Faso. 
[32] Diop, A. (2013) Diagnostic des pratiques d'utilisation et quantification des pesticides dans la zone des Niayes de Dakar (Sénégal). Mémoire de doctorat Université du Littoral Côte d'Opale.

[33] Obuodi, E., Keraita, B., Danso, G., Amoah, P., Kofie, O.O., Rashid-Sally, L. and Drechsel, P. (2006) Irrigated Urban Vegetable Production in Ghana: Characteristics, Benefits and Risks. IWMI-RUAF-CPWF, Accra.

[34] Mougeot, L.J.A. (2000) Urban Agriculture: Definition, Presence, Potential and Risks. In Growing Cities, Growing Good: Urban Agriculture on the Policy Agenda, à Reader on Urban Agriculture. Feldafing, Allemagne.

[35] Amouzou, K., Adake, B., Batawila, K., Wala, K., Akpavi, S., Kanda, M., Odah, K. Kossititrikou, K., Butare, I., Bouchet, P. and Akpagana, K. (2006) Etudes biochimiques et évaluation des valeurs nutritionnelles de quelques espèces alimentaires mineures du Togo. Acta Botanica Gallica, 153, 147-152.

https://doi.org/10.1080/12538078.2006.10515533

[36] Dongmo, T., Gockowski, J., Hernandez, S., Awono, L.D. and Moudon, M. (2005) L'agriculture périurbaine à Yaoundé: ses rapports avec la réduction de la pauvreté, le développement économique, la conservation de la biodiversité et de l'environnement. Tropicultura, 23, 130-135.

[37] Tallaki, K. (2006) Pest Control System in the Market Gardens of Lomé, Togo. Thesis, Department of Rural Development and Agroecology (DRDAg). Swedish University of Agricultural Sciences, Togo.

[38] Kouakou, K.J., Yao, K.B., Sika, A.E., Gogbeu, S.J., Koné, L.S. and Dogbo, D.O. (2019) Caractérisation de l'activité de maraîchage dans la commune de Port-Bouët (Abidjan, Côte d'Ivoire). Journal of Animal \& Plant Sciences, 41, 6747-6756. https://doi.org/10.35759/JAnmPlSci.v41-1.2

[39] Ngom, S., Traore, S., Thiam, M.B. and Anastasie, M. (2012) Contamination des produits agricoles et de la nappe phréatique par les pesticides dans la zone des Niayes au Sénégal. Synthèse. Revue des Sciences et de la Technologie, 25, 119-130.

[40] Akogbeto, M.C., Djouaka, R. and Noukpo, H. (2005) Use of Agricultural Insecticides in Benin. Bulletin de la Société de Pathologie Exotique, 98, 400-405.

[41] Son, D., Somda, I., Legreve, A. and Schiffers, B. (2017) Pratiques phytosanitaires des producteurs de tomates du Burkina Faso et risques pour la santé et l'environnement. Cahier Agricultures, 26, 25005-25015. https://doi.org/10.1051/cagri/2017010

[42] Gomgnimbou, A.P.K., Savadogo, P.W., Nianogo, A.J. and Millogo, R.Y.J. (2009) Usage des intrants chimiques dans un agrosystème tropical: Diagnostic du risque de pollution environnementale dans la région cotonnière de l'est du Burkina Faso. Biotechnologie, Agronomie, Société et Environnement, 13, 499-507. 